resources and the Minister thought it is entirely right to retard the programme slightly, making up the difference by conventional power stations.

In reply to questions about ZETA, Lord Mills said that while the production of a thermonuclear reaction under controlled conditions has been demonstrated as a practical possibility, the stage reached is comparable with that attained in 1938 when it was first demonstrated that if the atom could be split energy would thereby be released. It took eighteen years to produce the Calder Hall station, which was the prototype of the nuclear power programme, and the problems associated with the controlled release of thermonuclear power are certainly no less formidable. The Government will ensure that full account is taken of all the potentialities opened up by the genius of our scientists and technologists but, even on the most optimistic assumption, it is scarcely conceivable that the present programme for nuclear power will need modification because of these further developments. Lord Mills also suggested that the availability of nuclear power and the removal of the pressure of demand for coal will enable the coal industry to be more selective in its output, both in terms of cost of production and of the kinds of coal produced. He agreed as to the importance of efficiency in consumption and professed himself satisfied with the arrangements for scientific advice. He is setting up a committee to consider improving co-operation between the Area Electricity and Gas Boards, and a pilot plant for underground gasification is under construction.

\title{
LIBRARIES
}

$\mathrm{E}^{\mathrm{sin}}$ AST met West at the one-day conference of the Scottish Branch of Aslib in the Scottish Central Library, Edinburgh, on February 7. Five speakers representing overseas countries, but all working in Great Britain, gave papers on different aspects of library and information work in Britain and in their own countries.

Miss Margaret Haferd, Librarian of the U.S. Information Service Library in London, spoke of the different useful services that her establishment could offer by way of information on work in America, and technical books.

The principal speaker of the meeting was Dr. J. C. Malloch, of the Scientific Liaison Office of the National Research Council of Canada. His paper was on "Technical Information in the Modern World". $\mathrm{He}$ pointed out how science and technology affect every aspect of daily life, food, clothing, and travel. Even the classicist often does not realize the absurdity of voicing his scorn of science on television and reads Thucydides more easily because a technologist has developed a better printer's ink.

Dr. Malloch suggested that to get the type of general education that is needed, schools and teachers must have available the basic technical information in the right form. He criticized the old dull text teaching Boyle's law, the valency of oxygen or the bones of a frog to students, many of whom will never need this information. He suggested it should be replaced by material which would convey the fascination of scientific discovery and a realization that it really means something to every individual, whatever walk of life they might choose. This is a challenge that cannot be ignored if science is to have the intelligent public support necessary to its development and proper use.

He next spoke about abstracting services, and the tremendous expansion of scientific work in the past twenty years, much of which never appeared in standard journals, and how it had materially altered the situation. While chemists and physicists were served by abstract journals, biologists were badly off. By their own figures, the coverage of Biological Abstracts is only about 40 per cent and the publica. tions of the Commonwealth Agricultural Bureaux cover only special fields, generally selectively. The industrial fields of applied science and engineering are virtually without abstracting services. We are now realizing the vast amount of important scientific and technical information that is available in the U.S.S.R., its satellites and China which is scarcely touched by most of the abstracting services and only available with difficulty in any form.

Scientists need help and this is a suitable task for information services, but one which must be carried out by methods agreeable to the working scientists. Many research organizations now make use of public relations or press officers whose duty it is to make known the activities of the laboratories and to present the results to the general public in an understandable form. Discoveries of science only become of immodiate importance to mankind when they are available for the general benefit. As a result of nearly fifteen years of experience Dr. Malloch believes that the personal approach of field-officers throughout the country is the best method of disseminating information to factories and industry. Dr. Malloch suggested the motto of a public relations officer of the National Research Council in Canada might well be adopted: "No sooner done than said".

Dr. Malloch then went on to describe in detail the work of the National Research Council of Canada. Its library is the major scientific library of Canada and is operated as a national service. It maintains an index of all the translations made of scientific papers in Canada and co-operates with the Commonwealth Index of Translations.

The afternoon session was devoted to papers on library work in their own countries by three ladies at present working in Edinburgh and Aberdeen libraries. Miss L. Somme, of Hammerfest, Norway, at present in Edinburgh, gave the picture of the growth of libraries in her country since the Second World War. Interest in reading had begun during the war when there was little else to do. Now each county had a main district library and attempts were being made to cover outlying districts by mobile libraries by road and sea. The purchasing and binding of books are carried out by the State. Librarians have a three-year course and, as there is a great lack of librarians, positions are easy to obtain.

Miss T. Visser from Utrecht said that in Holland, owing to religious beliefs, it was quite common to find in any one town three public libraries, one neutral, one Roman Catholic and one Calvinistic, 
each getting State grants. All, however, are members of the Central Association of Public Libraries, which is responsible for the training and placing of librarians. Special libraries were late in commencing and are now organized by the Netherlends Institute for Documentation and Organization of Libraries. A very useful tool for Dutch librarians is the Union List of Periodicals held in the 166 libraries in the Nethorlands maintained by the Royal Library at the Hague.
Miss De Silva, at present in Aberdeen, spoke of the differences between the libraries in Ceylon, Kenya and the United Kingdom. She pointed out that the two eastem countries were backward and not well equipped. Both countries were similar in basing their libraries upon British methods and Ceylon was the more advanced. There are three libraries in Kenya, the Macmillan Library for Europeans, one for Africans only and one general. J. R. K. PIRIE

\section{EXOTIC FOREST TREES IN GREAT BRITAIN}

$\mathbf{I}_{\mathrm{n}}^{\mathrm{T}}$ is held that Great Britain contains a larger number of exotic trees than any other country, some of which have been well known for a long time. These have adapted themselves to soils and climate so well that they are regarded as indigenous species. This abundance conceals our poverty of native trees, especially conifers, among which the only natives are the Scots pine, the yew and the juniper, the latter little more than a straggling bush. Among broad. leaved trees the difference is not so great, but even in this group familiar trees such as the sycamore, the horse chestnut and the plane have been introduced in historic times. The sycamore is notable for its rapid growth in youth, for the lovely tree produced and its great fertility, young seedlings springing profusely from the seed shed in most years.

The Forestry Commission has recently published Bulletin No. 30 on "Exotic Trees in Great Britain", prepared by Messrs. James Macdonald, R. F. Wood, M. V. Edwards and J. R. Aldhous for the British Commonwealth Conference held last July in Australia and New Zealand (H.M. Stationery Office, 1957). The Scots pine formed forests in the Highlands of Scotland, but the Norway spruce, now so common in Britain, was absent. The beech was native only in the south of England and absent from the deciduous forest dominated by oak in the rest of the country. This is in marked contrast with France, where the great oak and beech forests are the glory of that country. Part 1 deals with general considerations affecting exotic forest trees in Great Britain; Part 2 exotic coniferous trees; and Part 3 exotic broad-leaved trees in Great Britain.

The poverty of the tree flora of the British Isles is attributed partly to geographical situation and partly to recent geological history. The introduction of exotic species was at first due to individuals who brought them in for æsthetic purposes on their estates. More recently, commercial motives have increased the rate of introduction of some species such as the sitka spruce and Douglas fir from North America and the Japanese larch. The European larch came in much earlier and was planted on private estates, but the Norway spruce and the silver fir were imported during the past two centuries.

The sitka spruce has been largely used in the twentieth century by the Forestry Commission in planting the new forests of Britain, as have the Japanese larch and the Corsican pine. Thirty-eight genera of conifers and twenty-two genera of broadleaved trees have been introduced into Britain.

\section{EUROPEAN ORGANIZATION FOR NUCLEAR RESEARCH}

\section{REPORT FOR 1956}

\begin{abstract}
THE second annual report of the European Organization for Nuclear Research (CERN), covering the period to the end of $1956^{*}$, is-as Prof. C. J. Bakker, the director-general of the Organization, remarks in his brief introduction-a straightforward account of development during the year, which indicates that rapid progress has been made in accerdance with the plan outlined in the previous annusl report (Nature, 178, 902; 1956). However, several years of intensive scientific and technical work still lie ahead before Europe's great joint laboratory for advanced nuclear research can begin to operate fully. Except for the high-frequency system the synchro-cyclotron was practically completed; it was expected to come into operation during 1957. The buildings for the proton synchrotron were also nearly finished and orders for most of the components of the accelerator have been placed. The many illustrations and photographs
\end{abstract}

- Second Annual Report of the European Organization for Nuclear Research (CWRN), 1956. Pp. vi + 71 (19 plates). (Geneva : European Organization for Nuclear Research, 1957.) given in the annual report show clearly the remarkable progress made in the construction of these two large accelerators and their associated buildings, and much detail of the layout and characteristies of the machines is also given in the two sections of the report devoted specially to them.

The purpose of the two-week symposium on highenergy accelerators and pion physics, organized by CERN and held in Geneva during June 1956, was to gather physicists from all over the world and thus enable the Organization to start playing the part for which it was intended as an international centre of advanced studies. 319 scientists from twenty-two countries, including some fifty American and an equal number of Russian scientists, attended. Most of the papers presented had been pre-printed either in English or French and were circulated before the conference. The discussions were recorded, and the proceedings were afterwards published in full in two volumes (see Nature, 179,$283 ; 1957$ ). It is proposed to hold a similar symposium in 1958. During the first week the principles and methods used in the con- 